\title{
Lorcaserin therapy for severe epilepsy of childhood onset
}

\section{A case series}

Patricia Tolete, Kelly Knupp, MD, Michael Karlovich, Elaine DeCarlo, RN, Judith Bluvstein, MD, Erin Conway, NP, Daniel Friedman, MD, Patricia Dugan, MD, and Orrin Devinsky, MD

Neurology ${ }^{\circledR}$ 2018;91:837-839. doi:10.1212/WNL.0000000000006432

Childhood-onset refractory epilepsies (e.g., Dravet syndrome [DS]) contribute to developmental delays, impaired quality of life, and increased mortality. We lack safe and effective antiseizure medications (ASMs) for these patients. Fenfluramine, an appetite suppressant, increases serotonin activity by releasing and inhibiting the reuptake of 5-HT and stimulating all 5-HT receptors. Combining fenfluramine with phentermine (Fen-Phen) led to sustained weight loss in obese patients, but pulmonary hypertension and heart valve lesions led to withdrawal. A small open-label trial with fenfluramine and a subsequent randomized trial found significant reductions in seizures in children with DS. ${ }^{1,2}$

Lorcaserin is a selective serotonin receptor $\left(5-\mathrm{HT}_{2 \mathrm{C}}\right)$ agonist with receptors limited to the CNS. Mice lacking 5- $\mathrm{HT}_{2 \mathrm{C}}$ receptors have a lower seizure threshold ${ }^{3}$ and lorcaserin reduced seizures in a zebrafish DS model. ${ }^{4}$ Lorcaserin does not affect cardiac valve $5-\mathrm{HT}_{2 \mathrm{~B}}$ receptors and was Food and Drug Administration-approved for weight loss. We examined lorcaserin as a potential ASM in patients with DS and other severe childhood-onset epilepsies since we are unaware of any mechanism that would limit the potential antiseizure effects of serotonergic agonists to patients with SCN1A mutations.

\section{Methods}

\section{Standard protocol approvals, registrations, and patient consents}

NYU Langone Health $(n=24)$, Children's Hospital of Colorado $(n=6)$, and RWJ Barnabas Health $(n=6)$ collaborated on this retrospective chart review (January 2014 to January 2018). The institutional review board at each center approved the study.

Clinical data were abstracted from medical records including demographics, epilepsy diagnosis and treatments, lorcaserin dosage and effects, and potential drug interactions. Seizure frequencies were ascertained from caregiver reports in patient charts. Tonic, tonic-clonic, focal seizures with prominent motor features, and drop (atonic) seizures were used for the primary efficacy outcome. The primary efficacy outcome was median percentage change in the mean monthly frequency of these motor seizures from baseline to last observation on lorcaserin. A 2-tailed Wilcoxson signed rank test assessed pretreatment/posttreatment changes.

\section{Results}

Of the 36 lorcaserin-treated patients, one was excluded from efficacy analysis because of discontinuation after 3 days due to side effects. Of the 35 remaining patients, 18 were female and treatment onset was 3-40 years (mean 16.4 years). Diagnoses included DS $(n=20)$,

\author{
Correspondence \\ P. Tolete \\ patricia.tolete@nyumc.org
}


Lennox-Gastaut syndrome (LGS) $(\mathrm{n}=9)$, and other treatment-resistant focal epilepsies $(n=3)$ and generalized epilepsies $(n=3)$. Thirty-three $(94.3 \%)$ patients were taking $\geq 1$ ASM (mean 3; clobazam [60\%], valproic acid [57.1\%], and cannabidiol $[40 \%]$ ).

Among our 35 patients, median percentage reduction in the mean monthly frequency of motor seizures from baseline was $47.7 \%(z=-3.04, p<0.01 ; 46.9 \%$ in tonic-clonic, $62.3 \%$ in tonic, $60.1 \%$ in atonic, and $54.6 \%$ in focal seizures with motor features); 15 (42\%) had a $>50 \%$ reduction in motor seizures. Two $(5.7 \%)$ patients had increased seizure frequency. The mean lorcaserin dosage was $15.7 \mathrm{mg} / \mathrm{d}$ (and $13.7 \mathrm{mg} / \mathrm{d}$ for children) and median treatment duration was 10.8 months. After 15 months, $50 \%$ of patients remained on lorcaserin (figure).

The most common adverse events were decreased appetite (19.6\%), decreased attentiveness (17.1\%), and weight loss (11.1\%). The mean decline in body mass index at last followup compared to baseline was $-0.58 \pm 0.24 \mathrm{~kg} / \mathrm{m}^{2}(-2.7 \pm$ $1.3 \% ; p=0.02)$ and was similar among patients taking or not taking valproate. Five patients stopped treatment before 30 days due to side effects.

\section{Discussion}

Our retrospective case series found that the selective $5-\mathrm{HT}_{2 \mathrm{C}}$ agonist lorcaserin may reduce motor seizures in children and young adults with treatment-resistant epilepsies. Lorcaserin was associated with a reduction of motor seizures in all groups: $50 \%$ in LGS, $43 \%$ in DS, and $23 \%$ in other epilepsies. Assuming a 10\%-20\% placebo response rate in epilepsy

Figure Kaplan-Meier plot demonstrating retention rate of patients started on lorcaserin $\mathrm{HCl}$

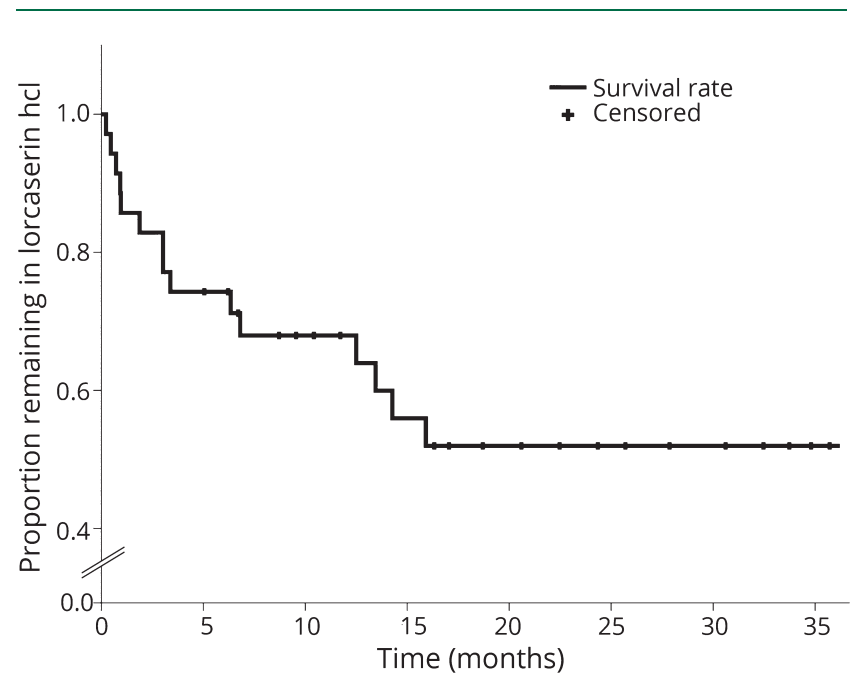

+Patients who were still receiving treatment at the time of efficacy review. trials, ${ }^{5}$ the LGS and DS groups appear to have a clinically significant improvement.

Serotonergic therapies may have proconvulsant or anticonvulsant properties in animal models and small case series. ${ }^{1,6} \mathrm{~A}$ meta-analysis of clinical trials found that patients randomized to second-generation antidepressants (excluding bupropion) had fewer seizures than those on placebo. ${ }^{7}$ Open-label and randomized trials show fenfluramine reduces convulsive seizures in DS. ${ }^{1}$ We included patients without DS since there is no mechanism to account for a selective efficacy of a serotonergic agonist in seizures due to SCN1A mutations.

Lorcaserin was well-tolerated in our patients. Adverse events reported by $>10 \%$ of patients were decreased appetite and attentiveness and weight loss. The patient excluded from the efficacy analysis developed serious behavioral side effects likely due to concomitant sertraline, suggesting serotonin syndrome. Another patient taking fluoxetine experienced no adverse events but stopped treatment before 30 days due to limited efficacy. The off-label use of lorcaserin was limited by high cost and limited insurance coverage, leading some families to discontinue therapy.

This study was limited by retrospective data collection, no control group or blinding, and small sample size. There was variation in both the timing of patient assessments and the consistency of clinical features. Caregiver reports are subject to recall bias. Patients did not undergo systematic evaluations before and after initiation of lorcaserin therapy (e.g., trough ASM levels, liver function tests, EEG). Adverse events were not systematically collected. ASM changes or other therapeutic adjustments may have affected seizure frequency. Interactions between ASMs or other concomitant medications and lorcaserin were not analyzed.

These promising preliminary findings support the need for randomized, controlled trials of lorcaserin for treatmentresistant epilepsies.

\section{Author contributions}

P. Tolete: study design, acquisition of data, analysis and interpretation of data, drafting or revising the manuscript for intellectual content. K. Knupp: study design, acquisition of data, analysis and interpretation of data, drafting or revising the manuscript for intellectual content. M. Karlovich: analysis and interpretation of data, drafting or revising the manuscript for intellectual content. E. DeCarlo: acquisition of data, analysis and interpretation of data. J. Bluvstein: acquisition of data, analysis and interpretation of data. E. Conway: acquisition of data, analysis and interpretation of data. D. Friedman: analysis and interpretation of data, drafting or revising the manuscript for intellectual content. P. Dugan: analysis and interpretation of data, drafting or revising the manuscript for intellectual content. O. Devinsky: study design, acquisition of data, analysis and interpretation of data, drafting or revising the manuscript for intellectual content. 


\section{Acknowledgment}

The authors thank Finding A Cure for Epilepsy and Seizures (FACES), which helped to support this study and continues to support many others in epilepsy research.

\section{Study funding}

No targeted funding reported.

\section{Disclosure}

P. Tolete reports no disclosures relevant to the manuscript. K. Knupp receives research funding from Zogenix, The Colorado Department of Public Health, PERF, and West Therapeutics and has funding from GW Pharmaceuticals as part of the DSMB. M. Karlovich, E. DeCarlo, J. Bluvstein, and $\mathrm{E}$. Conway report no disclosures relevant to the manuscript. D. Friedman receives salary support from the Epilepsy Study Consortium, has consults or serves on advisory boards for Adamas Pharmaceuticals, Eisai, GW Pharmaceuticals, Penumbra, Supernus, and UCB, and has received honoraria for educational materials from Neuropace. P. Dugan reports no disclosures relevant to the manuscript. O. Devinsky received funding from the National Institute of Neurologic Disorders and Stroke for SUDEP Research and serves as the Principal Investigator of the North American SUDEP Registry and Sudden Unexpected Death in Childhood Registry and Research Collaborative and has received research grants from GW Pharmaceuticals, Zogenix, Novartis, and PTC Therapeutics. Go to Neurology.org/ $\mathrm{N}$ for full disclosures.

\section{Publication history}

Received by Neurology April 4, 2018. Accepted in final form July 31, 2018.

\section{References}

1. Ceulemans B, Boel M, Leyssens K, et al. Successful use of fenfluramine as an add-on treatment for Dravet syndrome. Epilepsia 2012;53:1131-1139.

2. Zogenix Announces Positive Top-line Results from Pivotal Phase 3 Clinical Trial of ZX008 in Dravet Syndrome [press release]. Nasdaq GlobeNewswire; 2017.

3. Griffin A, Hamling KR, Knupp K, Hong S, Lee LP, Baraban SC. Clemizole and modulators of serotonin signalling suppress seizures in Dravet syndrome. Brain 2017; 140:669-683.

4. Venzi M, David F, Bellet J, et al. Role for serotonin2A (5-HT2A) and 2C (5HT2C) receptors in experimental absence seizures. Neuropharmacology 2016; 108:292-304.

5. Guekht AB, Korczyn AD, Bondareva IB, Gusev EI. Placebo responses in randomized trials of antiepileptic drugs. Epilepsy Behav 2010;17:64-69.

6. Hargrave R, Martinez D, Bernstein AJ. Fluoxetine-induced seizures. Psychosomatics 1992;33:236-239.

7. Alper K, Schwartz KA, Kolts RL, Khan A. Seizure incidence in psychopharmacological clinical trials: an analysis of Food and Drug Administration (FDA) summary basis of approval reports. Biol Psychiatry 2007;62:345-354.

\section{Add Your Voice! Apply for 2019 Neurology on the Hill}

The AAN continues to fight for common sense health care reform that promotes neurology and protects your patients. Add your voice to the conversation at Neurology on the Hill from February 25 to 26, 2019, and help educate members of Congress so we can address critical health policy problems together. If selected, you will receive training to bring you up-to-date on key issues. Then, you will go to Capitol Hill for face-to-face meetings with congressional members and their staffs.

Learn more and apply by November 2, 2018, at AAN.com/view/NOH.

\section{Disputes \& Debates: Rapid online correspondence}

The editors encourage comments on recent articles through Disputes \& Debates:

Access an article at Neurology.org/ $N$ and click on "COMMENT" beneath the article header. Responses will be posted within 3 business days.

Before submitting a comment to Disputes \& Debates, remember the following:

- Disputes \& Debates is restricted to comments about studies published in Neurology within the last eight weeks

- Read previously posted comments; redundant comments will not be posted

- Your submission must be 200 words or less and have a maximum of five references; reference one must be the article on which you are commenting

- You can include a maximum of five authors (including yourself) 


\section{Neurology}

\section{Lorcaserin therapy for severe epilepsy of childhood onset: A case series}

Patricia Tolete, Kelly Knupp, Michael Karlovich, et al.

Neurology 2018;91;837-839 Published Online before print September 26, 2018

DOI 10.1212/WNL.0000000000006432

This information is current as of September 26, 2018

Updated Information \&

Services

References

Subspecialty Collections

Permissions \& Licensing

Reprints including high resolution figures, can be found at: http://n.neurology.org/content/91/18/837.full

This article cites 6 articles, 0 of which you can access for free at: http://n.neurology.org/content/91/18/837.full\#ref-list-1

This article, along with others on similar topics, appears in the following collection(s):

All Epilepsy/Seizures

http://n.neurology.org/cgi/collection/all_epilepsy_seizures Antiepileptic drugs

http://n.neurology.org/cgi/collection/antiepileptic_drugs

Information about reproducing this article in parts (figures,tables) or in its entirety can be found online at:

http://www.neurology.org/about/about_the_journal\#permissions

Information about ordering reprints can be found online:

http://n.neurology.org/subscribers/advertise

Neurology ${ }^{\circledR}$ is the official journal of the American Academy of Neurology. Published continuously since 1951, it is now a weekly with 48 issues per year. Copyright Copyright (C) 2018 The Author(s). Published by Wolters Kluwer Health, Inc. on behalf of the American Academy of Neurology.. All rights reserved. Print ISSN: 0028-3878. Online ISSN: 1526-632X.

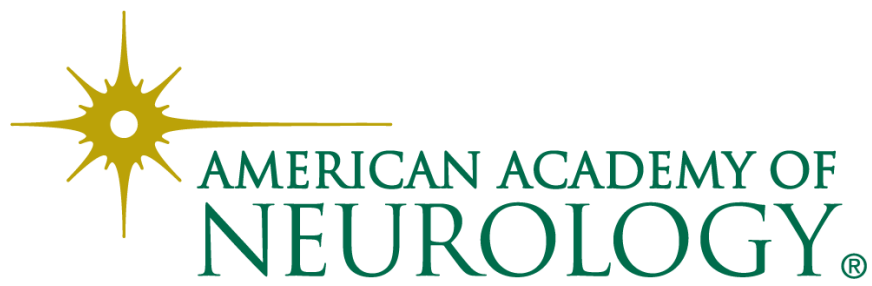

